\title{
Asperger's Syndrome with depression and substance abuse: First-time presentation and diagnosis in a 64-year old man
}

\author{
Sayantani Mukherjee \\ Department of Psychiatry, Chaitanya Institute for Mental Health, survey no. 31/A, Kondhwa, near Khadi \\ Machine Chowk, Bhagat Puram, Pune - 411048, Maharashtra, India. \\ Corresponding author: Sayantani Mukherjee \\ Email-drsayantani25@gmail.com
}

\begin{abstract}
Autism spectrum disorders (ASD) rarely are brought to clinical notice in geriatric population. This case is of a 64 years old gentleman with high-functioning ASD (diagnosed as Asperger's Syndrome) presenting for social/ communication deficits affecting his personal life and career, resulting in depression and substance abuse. His family was skeptical about his symptoms. He was successfully treated for depression and substance abuse; CBT, psychoeducation, individual therapy, social skills training were done to help him cope with his ASD symptoms. Family therapy was done to improve the family's understanding of ASD and bonding with him. After 1 year of treatment, he is thriving in all aspects - better family relations, career management and personal emotional well-being. This opens up a discussion regarding undiagnosed ASD in older adults and elderly, comorbidities, the resulting community mental health burden which goes neglected, and therefore the need for more vigilant detection, and treatment options.
\end{abstract}

Key words: Asperger's Syndrome; autism spectrum disorders; geriatric; older adults; diagnosis; comorbidities

(Paper received $-6^{\text {th }}$ October 2019, Peer review completed $-8^{\text {th }}$ October 2019)

(Accepted $-9^{\text {th }}$ October 2019)

\section{INTRODUCTION}

When we think of autism spectrum disorders (ASD), it generally evokes pediatric and adolescent first-time presentations; elderly population exclusively seeking help for what turned out to be ASD with secondary mental health concerns are few and far between. Adult/ geriatric ASD generally come to clinical notice when they present with subsequent psychiatric issues like depression, anxiety, psychosis, substance abuse or co-morbid neurodevelopmental conditions like attention deficit and sensorimotor dysfunctions [1]. The following case is of a first-time diagnosis of Asperger's Syndrome (AS) with depression and substance abuse in a 64 years old man.

\section{CASE REPORT}

A 64 yearS old gentleman Mr. X came along with his family to Psychiatry services OPD with chief complaint that he felt sad as he couldn't understand how to socially interact correctly. Since childhood, he has had poor eye contact, limited facial expressions, poor ability to make friends, meagre understanding of sarcasm, jokes and double meanings, little capacity to empathize and disproportionate displays of anger (he is perceived to be angrier than he feels). He has never been good at expressing his emotions, understanding non-verbal communication, interpreting body language or intuiting social communication. He has a habit of making circling gestures on surfaces (e.g. table) with his fingers, especially when he is agitated/ attempting to focus on something he finds unpleasant. He says he was never bothered till recently regarding his social inadequacies; he felt he was slightly eccentric but never had fear of being socially rejected (rather, he felt 
most people did not share any common interests with him and therefore he preferred not to interact with them). He was academically brilliant in Physics and Mathematics in school. He had an arranged marriage at the age of 18 years. He stayed away from family for his job for almost 35 years. Last 3.5 years, he has been staying with family. Since then, he has constant tiffs with his family over his behavior where they tell him he is intentionally being obtuse and not making an effort and he explains that he is just not able to understand when they say one thing and mean another. He asks for short clear instructions, has a very narrow comfort zone and has a certain rigidity in managing his work and daily life. The other members of his family (wife, 2 children), in contrast, are very social, and felt he is socially (and physically) clumsy, avoidant of people and situations where a lot of small talk is required and that he tended to be lost in his own world. Mr. X said he communicates better with the family over written medium than face to face as then he doesn't have to attempt to interpret their tone, facial expression etc. However, he did have meaningful emotional relations with his family, satisfactory sexual relationship with wife as well as 2 close friendships that have sustained over 30 years. He is working as a software consultant in a video game development company and on enquiry, he said he chose this field because he had excellent skills in terms of this kind of software development (otherwise he thinks he had a limited skill set) and it requires minimal interactions with people, so he feels at ease. He tended to avoid meeting clients, again to escape small talk. He preferred focused detailed conversations on topics of his own interest where he could speak very well and at length. He has quite limited fields of interest in which he spends all his time - coding, pure mathematics, listening to 1980s' pop music and collecting those records, playing the piano and the violin. The family reported that he would exclusively pursue these activities at home, especially if he was unhappy. They felt he was faking this communication problem as he did not like socializing/ giving them time and therefore constantly blamed him. His birth and development history and family history, as far as known, was unremarkable. He was hypertensive and hypercholestremic and was maintained on amlodipine $5 \mathrm{mg}$ and atorvastatin $10 \mathrm{mg}$ since the past 7 years; there was no significant history of medical issues/ organicity otherwise.

At the time of presentation, he had low mood, poor sleep, easy fatigability and irritability. Regarding his communication difficulties, he was angry with the family for failing to understand him as they knew he finds general chit-chat very boring; he felt astonished that this issue is so important to everybody and hence was impairing his life so much, and frustrated with himself because it was beyond his capabilities to overcome this. These symptoms had been there since 3 years but has intensified since about 1 month after a professional setback that happened as a fallout of his poor social skills (he felt he had a healthy debate with a client whereas the client felt that he was very loud and angry and so escalated the matter to the company HR department). He was afraid of losing his career which is a dearly held vocation for him, and so had some crying spells and feelings of helplessness and worthlessness. Over last 2 years, he had become addicted to nicotine (cigarette smoking, 8 sticks/day) and alcohol (whisky, binge-pattern, 2-3 QTR/ sitting, 2-3 times a month) in pursuit of relief from his depressive symptoms. He came to Psychiatry services to find out whether he really had a communication/ social skills problem, and if yes, how he could improve it as he felt it was upsetting his life and consequently, him; he also wanted to be de-addicted from nicotine and alcohol. $\mathrm{He}$ had never undergone any evaluation for these issues in the past.

Of salience in mental status examination, he had poor eye to eye contact but established a good rapport and sustained attention during interview, had stereotypical hand movements, low mood, ideations of helplessness, worthlessness but intact judgment and insight $5 / 6$. He was diagnosed (see Table 1) with Asperger's syndrome (F 84.5), moderate depressive disorder (F32.1), alcohol harmful use (F1x.1) and nicotine dependence (cigarettes, uncomplicated) (F17.210) [as per ICD-10] and treated accordingly (see Table 2).

Presently patient says his AS diagnosis has brought him relief from guilt regarding his social awkwardness and improved self-esteem as he continues to work actively to better it.

\section{DISCUSSION}

An American study pegs the prevalence of AS in young adults at $0.7 \%-1.9 \%$ [7]. No concrete epidemiological data could be found regarding its prevalence in geriatric or adult global/ Indian population. 
Though the epidemiology of ASD in Indian children is being studied regularly (latest pooled percentage prevalence 0.09-0.11), recent studies and meta-analyses alike have lamented the lack of high-quality epidemiological data regarding ASD in Indian adult population and it is surmised that due to it, they would have a substantial undiagnosed mental health burden [8-10].

It is not unusual for people with AS to have mental health issues due to their poor interpersonal and communication skills. Often clinically undetected, especially in context of adult population, it can lead to depression, mood disorders, anxiety, worsening of self-isolating behaviors, poor self-esteem, suicidality, psychosis, addictions and other sundry mental and behavioral disorders. Being shunned by family and society only leads to further aggravation as they cannot form any gainful emotional relationships, have difficulty with employment and a poorer quality of life. Even if they have average IQ, they may still have co-morbid attention deficit, hyperactivity, and variable neurological deficits. Mr. X did actively want to seek help for the social/communication deficit and the following depression and addictions; unlike him, even though it is common to seek help for the secondary mental health disorders, very few manage to understand and seek help for the core ASD symptoms [1,8, 11-12].

Once diagnosed, treating such cases can have challenges in terms of limitations in treatment options and long duration of untreated condition. If the person is high-functioning, CBT has been tried with some modicum of success [13], as seen here. Else, treatment should entail multi-disciplinary collaboration with psychopharmacology, supportive psychotherapy/ education, de-stigmatizing and improving family's approach towards the patient, polishing up social skills through specific training, occupational therapy for sensory/fine motor issues if present, as well as treating the secondary psychiatric complications. Each case ought to be approached eclectically, and if there are cognitive deficits, lack of employment or social support, they should be helped to avail government concessions/ aid and additionally referred to social services or agencies that work with ASD persons for life-long social, occupational, financial and legal support as necessitated $[1,8,11,14-15]$.

Proactively sensitizing family and community regarding ASD might go a long way in increasing detection, treatment and reducing the community mental health burden. For high-functioning ASD, specially screening adults with low global functioning and employees of STEM [science, technology, engineering, mathematics] theoretical and research fields (as selected AS individuals tend to gravitate towards these niche fields) can prove fruitful [14]. As mental health professionals working in India, to understand better the scope of adult ASD from epidemiological, management and research point of view, we should widen our traditional child-centric focus to include adults, working and geriatric populations.

TABLE 1: Differential diagnosis (as by ICD-10) [2]

\begin{tabular}{|c|c|c|c|}
\hline Asperger's syndrome & $\begin{array}{l}\text { Anxious [avoidant] } \\
\text { personality disorder }\end{array}$ & $\begin{array}{l}\text { Schizoid personality } \\
\text { disorder }\end{array}$ & $\begin{array}{l}\text { Anankastic personality } \\
\text { disorder }\end{array}$ \\
\hline $\begin{array}{l}\text { Consists of childhood } \\
\text { onset, more in males, } \\
\text { physical clumsiness, } \\
\text { qualitative multiple } \\
\text { impairments of using } \\
\text { non-verbal behaviors/ } \\
\text { gestures, restricted } \\
\text { repetitive stereotyped } \\
\text { patterns of behavior/ } \\
\text { interest/ motor } \\
\text { mannerisms without any } \\
\text { clinically significant } \\
\text { delay in language/ } \\
\text { cognitive milestones }\end{array}$ & $\begin{array}{l}\text { Consists of pervasive } \\
\text { pattern of tension, belief } \\
\text { one is personally } \\
\text { unappealing, excessive } \\
\text { preoocupation with } \\
\text { being criticized in social } \\
\text { situations, unwilling to } \\
\text { be involved unless } \\
\text { certain of being liked, } \\
\text { avoiding interpersonal } \\
\text { contact due to fear of } \\
\text { rejection all becoming } \\
\text { prominent early } \\
\text { adulthood. }\end{array}$ & $\begin{array}{l}\text { Consists of pervasive } \\
\text { pattern of detachment } \\
\text { from social } \\
\text { relationships, lack of } \\
\text { interest in family/ } \\
\text { sexual relationships, } \\
\text { flattened affect, lacking } \\
\text { close friends any } \\
\text { confidantes, taking } \\
\text { pleasure in almost no } \\
\text { activity, prone to } \\
\text { internal fantasizing, all } \\
\text { becoming prominent in } \\
\text { early adulthood. }\end{array}$ & $\begin{array}{l}\text { Consists of pervasive } \\
\text { pattern of perfectionism, } \\
\text { excess caution, } \\
\text { preoccupation with details, } \\
\text { neatness, excessive } \\
\text { conscientiousness, rigidity } \\
\text { and unreasonable } \\
\text { stubbornness, sometimes } \\
\text { insistent and unwelcome } \\
\text { thoughts, all becoming } \\
\text { prominent in early } \\
\text { adulthood. }\end{array}$ \\
\hline
\end{tabular}




\begin{tabular}{|c|c|c|c|}
\hline $\begin{array}{l}\text { LIKELY DIAGNOSIS } \\
\text { IN THIS CASE AS: } \\
\text { Childhood onset } \\
\text { Male gender } \\
\text { No delay in } \\
\text { communication } \\
\text { milestones } \\
\text { Poor eye contact } \\
\text { Limited facial expression } \\
\text { Unable to make friends } \\
\text { due to lack of } \\
\text { communication skills } \\
\text { despite desire to do so, } \\
\text { but very content to be by } \\
\text { himself pursuing his } \\
\text { interests } \\
\text { Academically gifted in } \\
\text { physics and math, and } \\
\text { later career points to } \\
\text { 'high-functioning' } \\
\text { Very narrow focus of } \\
\text { interest } \\
\text { Lack of social reciprocity } \\
\text { Physically clumsy } \\
\text { Stereotyped mannerism } \\
\text { in form of circular } \\
\text { movements with fingers }\end{array}$ & $\begin{array}{l}\text { NOT LIKELY } \\
\text { DIAGNOSIS AS IN } \\
\text { THIS CASE: } \\
\text { Childhood onset } \\
\text { Avoids social activities } \\
\text { as he finds } \\
\text { communicating tedious } \\
\text { but he has no fear of } \\
\text { social rejection/ } \\
\text { embarrassment } \\
\text { Is quite obtuse to } \\
\text { criticisms about his } \\
\text { social behaviour } \\
\text { Finds others boring if } \\
\text { they do not talk about } \\
\text { something that interests } \\
\text { him, rather than having } \\
\text { any sense of } \\
\text { hypersensitivity to } \\
\text { negative evaluation }\end{array}$ & $\begin{array}{l}\quad \text { NOT LIKELY } \\
\text { DIAGNOSIS AS IN } \\
\quad \text { THIS CASE: } \\
\text { Childhood onset } \\
\text { Has lasting close } \\
\text { friendships } \\
\text { Cares adequately about } \\
\text { family relationships } \\
\text { Enjoys sexual } \\
\text { relationship with wife } \\
\text { Immensely enjoys } \\
\text { activities falling into his } \\
\text { area of interest } \\
\text { No significant } \\
\text { fantasizing }\end{array}$ & \begin{tabular}{l}
\multicolumn{1}{c}{ NOT LIKELY } \\
DIAGNOSIS AS IN THIS \\
$\quad$ CASE: \\
Childhood onset \\
Though rigid, has no \\
preoccupation with \\
neatness/ perfectionism \\
No insistent/ unwelcome \\
thoughts \\
Also, anankastic personality \\
disorder does not entail \\
communication difficulties.
\end{tabular} \\
\hline
\end{tabular}

Table 2: Management and recovery progression

\section{REFERRALS}

General medicine: continue medications for hypertension and hypercholestremia.

Ophthalmology: existing refractive error confirmed; has corrective spectacles

ENT: nil active

Neurology: nil active; good cognitive functioning

Occupational therapist: no major sensory/ fine motor issues

Clinical psychologist: Diagnostic: IQ by Wechsler's Adult Intelligence Scale: 132;

Therapeutic: later for CBT, social skills training

Genetic screening was not done due to family's reluctance.

\section{INVESTIGATIONS}

CBC, blood sugar levels, Hb1Ac, liver and renal functions, thyroid functions, serum vitamin B 12, D3, homocysteine levels, and MRI brain were all within normal limits

MANAGEMENT AND RECOVERY

\begin{tabular}{|c|c|c|c|c|}
\hline Condition & $\begin{array}{c}\text { At first } \\
\text { presentation }\end{array}$ & After 2 months & After 6 months & After 1 year \\
\hline Depression & $\begin{array}{l}\text { HAM-D * score: } \\
24 \text { (moderate } \\
\text { depression) } \\
\text { Tab Escitalopram } \\
\text { 10mg HS }\end{array}$ & $\begin{array}{l}\text { HAM-D score:15 } \\
\text { (mild depression) } \\
\text { Tab Escitalopram } \\
\text { 10mg HS }\end{array}$ & $\begin{array}{l}\text { HAM-D score: } 06 \\
\text { (no depression) } \\
\text { Tab Escitalopram } \\
\text { 10mg HS }\end{array}$ & $\begin{array}{l}\text { HAM-D score: } 01 \\
\text { (no depression) } \\
\text { Tab Escitalopram } \\
5 \mathrm{mg} \text { HS }\end{array}$ \\
\hline
\end{tabular}




\begin{tabular}{|c|c|c|c|c|}
\hline $\begin{array}{c}\text { Alcohol } \\
\text { abuse }\end{array}$ & $\begin{array}{l}\text { Tablet Lorazepam } \\
\text { 2mg HS } \\
\text { Abstinence } \\
\text { advised }\end{array}$ & $\begin{array}{l}\text { Tablet Lorazepam } \\
1 \text { mg HS } \\
\text { Did not opt for } \\
\text { anti-craving } \\
\text { medications } \\
\text { Abstinence } \\
\text { maintained }\end{array}$ & $\begin{array}{l}\text { Tapered and } \\
\text { stopped } \\
\text { Lorazepam } \\
\text { Maintaining } \\
\text { abstinence } \\
\text { No craving } \\
\text { Avoids vicinity of } \\
\text { alcohol }\end{array}$ & $\begin{array}{l}\text { Maintained } \\
\text { abstinence } \\
\text { No craving } \\
\text { Has attended events } \\
\text { with alcohol, but no } \\
\text { craving/ } \\
\text { consumption }\end{array}$ \\
\hline $\begin{array}{c}\text { Nicotine } \\
\text { dependence } \\
\text { (cigarette) }\end{array}$ & $\begin{array}{l}\text { Consuming } 8 \\
\text { sticks/day } \\
\text { Patient expressed } \\
\text { willingness to cut } \\
\text { down by himself; } \\
\text { refused } \\
\text { medications }\end{array}$ & $\begin{array}{lr}\text { Consuming } & 5 \\
\text { sticks/ day } & \\
\text { Increased } & \text { craving } \\
\text { especially } & \text { after } \\
\text { prolonged } & \text { social } \\
\text { interactions } & \end{array}$ & $\begin{array}{l}\text { Consuming } 2 \\
\text { sticks/ day } \\
\text { Craving much } \\
\text { reduced } \\
\text { Using ginger } \\
\text { candy/ fennel } \\
\text { seeds to substitute } \\
\text { cigarette }\end{array}$ & $\begin{array}{l}\text { Maintaining total } \\
\text { abstinence since } 2 \\
\text { months } \\
\text { No craving } \\
\text { (feels motivated by a } \\
\text { sense of } \\
\text { accomplishment } \\
\text { after quitting both } \\
\text { alcohol and } \\
\text { nicotine) }\end{array}$ \\
\hline ASD & $\begin{array}{l}\text { ISAA score: } 103 \\
\text { Psychoeducation } \\
\text { for patient and } \\
\text { family done } \\
\text { CBT started }\end{array}$ & $\begin{array}{l}\text { ISAA score: } 100 \\
\text { CBT continued } \\
\text { Family therapy } \\
\text { done } \\
\text { Social skills } \\
\text { training started }\end{array}$ & $\begin{array}{l}\text { ISAA score: } 94 \\
\text { CBT continued } \\
\text { Social skills } \\
\text { training continued }\end{array}$ & $\begin{array}{l}\text { ISAA score: } 82 \\
\text { (improved in eye } \\
\text { contact, social smile, } \\
\text { responding to social } \\
\text { cues and taking turn } \\
\text { in interaction, } \\
\text { reduced delayed } \\
\text { response, reduced } \\
\text { aggression/ temper } \\
\text { tantrums/ } \\
\text { exaggerated } \\
\text { emotions) } \\
\text { CBT over } \\
\text { Social skills training } \\
\text { 'brush-up' sessions } \\
\text { still continued but } \\
\text { less frequently }\end{array}$ \\
\hline
\end{tabular}

${ }^{*} H A M-D=$ Hamilton's Depression Rating Scale: Given by Hamilton in 1960, well-known, 17 item, globally used scale with good psychometric properties (internal reliability 0.46-0.97, inter-rater reliability 0.82-0.98, test-retest reliability 0.81-0.98) to rate severity of depression. Interpretation: 0-7: no depression; 8-16: mild depression; 17-23: moderate deression;24-52: severe depression. [3]

**ISAA = Indian Scale for Assessment of Autism: given by National Institute for the Mentally Handicapped in 2009, used widely in Indian studies, with acceptable psychometric properties (inter-rater reliability 0.83 , test-retest reliability 0.89) to rate severity of autism. Interpretation: <70: no autism; 70-106: mild autism; 107-153: moderate autism; >153: severe autism [4-6]

*** ISAA was used here as, in its manual, there is no age limit mentioned but it is mentioned that this can be used for all persons with autism; studies have shown that it has been used in adults previously; [4,5] rating was done after observing and interviewing patient as well as interviewing his wife and mother (86 years, cognitively sound). 


\section{REFERENCES}

1. Murphy CM, Wilson CE, Robertson DM, Ecker C, Daly EM, Hammond N, et al. Autism spectrum disorder in adults: diagnosis, management, and health services development. Neuropsychiatr Dis Treat 2016;12:166986.

2. The ICD-10 Classification of Mental and Behavioural Disorders. CWorld Health Organisation, Geneva. Reprint, Delhi (India): A.I.T.B.S. Publishers and Distributors; 2007.

3. Chapter 42: Hamilton Rating Scale for Depression. In: Shahid A, editor. STOP, THAT and One Hundred Other Sleep Scales. 1st ed. New York City (NY): Springer Science and Business Media, 2012; pp. 187-190.

4. The National Institute for Mentally Handicapped (NIMH), Delhi, India. Indian Scale for Assessment of Autism (ISAA). 1st ed. Delhi (India): The National Trust, Ministry of Social Empowerment and Justice, Govt. of India; 2009.

5. Chakraborty S, Thomas P, Bhatia T, Nimgaonkar VL, Deshpande SN. Assessment of severity of autism using the Indian Scale for Assessment of Autism. Indian J Psychol Med 2015;37(2)169-74.

6. Mukherjee SB, Malhotra MK, Aneja S, Chakraborty S, Deshpande SN. Diagnostic accuracy of Indian Scale for Assessment of Autism (ISAA) in children aged 2-9 years. 2015. Indian Pediatr 2015;52(1):212-16.

7. White SW, Ollendick TH, Bray BC. College students on the autism spectrum: Prevalence and associated problems. Autism 2011;15(6): 683-701.

8. Patra S. Autism spectrum disorder in the elderly: a review of healthcare issues and challenges. J Geriatr Care Res 2016; 3(1):3-6.

9. Juneja M, Sairam S. Autism Spectrum Disorder -An Indian Perspective. In: Juneja M, (editor). Recent Advances in Autism. 1st ed. Mumbai (India): SM Group, 2018. pp.1-15.

10. Chauhan A, Sahu JK, Jaiswal N, Kumar K, Agarwal A, Kaur J, et al. Prevalence of autism spectrum disorder in children: A systematic review and meta-analysis. Neurol India 2019;67:100-4.

11. Barnhill GP. Outcomes in adults with Asperger Syndrome. Focus Autism Other Dev Disabil 2007;22(2): 11626.

12. Lugnegard T, Gillberg C. Psychiatric comorbidity in young adults with a clinical diagnosis of Asperger syndrome. Res Dev Disabil 2011;32(5):1910-7.

13. Gaus VL. Cognitive behavioral therapy for adults with autism spectrum disorder. Adv Ment Health Intellect Disabil 2011;5(5):15-25.

14. Wilkinson LA. Adults with Asperger Syndrome: A childhood Disorder Grows Up. Minneapolis (MN): Education Resources Information Center, Institute of Education Sciences of the United States Department of Education; c2007 [cited 06 Nov 2019]. Available from: www.eric.ed.gov.

15. Griffith GM, Totsika V, Nash S, Hastings RP. 'I just don't fit anywhere': support experiences and future support needs of individuals with Asperger syndrome in middle adulthood. Autism 2011;16(5):532-46.

$* * * * * * * * * * * * * * * * * * * * * * * * * * * * * * * * * * * *$

Acknowledgements - Nil

Conflict of Interest - Nil;

Funding - Nil 